\title{
A New Genesis: Rethinking Gender Expressions in Ursula K. Le Quin's The Left Hand of Darkness
}

\author{
Shu-Yuan Chang
}

\author{
School of Foreign Languages, Zhaoqing University, 526061, Guangdong, China \\ Corresponding author.Email: 2145632932@qq.com
}

\begin{abstract}
Ursula K. Le Quin's The Left Hand of Darkness focuses on humanity in which she interrogates the system of dichotomies such as male/female, self/other, light/dark and shift/mind speech. Le Guin's concern with the dichotomy of sex/gender is shown in Genly Ai's perspectives on the biological sexual differences between Ekumen and Gethen. The androgynous society on Gethen, a sharp contrast to the heterosexual society, brings Ai both cultural and biological shocks. The Left Hand of Darkness compels readers to rethink how a culture development is influenced by the concepts of sex and gender. This paper analyzes the gender expression which is associated with the formation in particular cultural context and stereotypes of gender. Le Guin interrogates factors related to the dichotomy of sex/gender and the development of the culture. The androgynous Gethenian Estraven displays that the achievement of individual integrity and humanity lies in the coexistence of the opposites.
\end{abstract}

Keywords: humanity, dichotomy, heterosexual, gender expression, androgynous, sex and gender, nature and nurture, integrity

\section{INTRODUCTION}

In her introduction of The Left hand of Darkness Le Guin argues, "Science fiction is metaphor" [5] and what the science fiction concerns is not about the future but about the present.

In The Left hand of Darkness, the protagonist Genly Ai, an ethnologist of the Ekumen of Known Worlds, comes to the planet Gethen to persuade its nations to join the Ekumen. His initial interaction with a Gethenian politician Harth Estraven and cognition of the planet uncover the dominant heterosexual concepts. The world of the ambisexual Gethen brings out the feminist debates of sex and gender and the evolvement of society and culture.

How the concept of sex and gender influences the operation of the society is revealed in Genly Ai's observations and perspectives on the biological sexual differences between Gethen and Ekumen. Before opening his mind to understand the culture of the ambisexual society, Ai observes everything on Gethen from an Earth-like perspective; in other words, he tends to judge the society from a heterosexual perspective.

In a heterosexual society, only female can bear children, so mothers are always women. Being a mother, a woman often becomes a "primary parent or caretaker" [1] in rearing children. Accordingly, the division of labor depends on one's biological sex. During the 1960 s to the 1970 s, the issue of sex and gender was the emphasis in feminist movement. Nowadays, the debate of sex and gender remains and it even extends to the fields of nature and culture. The differences of biological sex determine how men and women behave so as to fulfill the social expectations.
The biological differences socially and culturally construct both sexes into stereotyped gender roles. Therefore, People's thought is determined by the biological sex and the masculine and feminine traits become inseparate from the gender roles. Namely, the natural dichotomy determines the social dichotomy. As Mark Rose said, "science-fiction world can be used to explore the nature and the limits of our own reality" [2], Le Guin's metaphorical planet Gethen provides a critical point of view for us to rethink sex and gender.

Le Guin's depictions of encounters between races deal with the ethnic differences, and her ambisexual planet Gethen challenges contemporary ideas about gender. The narrative of The Left hand of Darkness alternates between Genly Ai and Harth Estraven, and four myths and legends are interwoven with their storytelling. Its narrative structure seems to be irrelevant initially; however, with the unfolding of the story, each chapter turns out to be closely related and echoes one another simultaneously.

In the following section the paper discusses gender concepts in Book of Genesis and Le Guin's Hainish universe, which demonstrates the opposite perspective to a heterosexual culture. Section 3 deals with androgyny and humanity in which nature and nurture are discussed to expose the connection between gender expressions and social constructs. The last section concludes Le Guin's concern with sex/gender dichotomy and the inspiration of her science fiction to readers. 


\section{FROM GENESIS TO BANISH UNIVERSE}

\subsection{Imperfect Man?}

Since Aristotle, the idea that the female is inferior to the male is prevalent. That woman is an imperfect man due to her biological sexual differences can be figured out from Book of Genesis. In Genesis, God creates the world by word in six days and makes the seventh as the holy day to rest. He creates the first human Adam by His own image. Adam is a complete, perfect human being while Eve, the first woman, is created from Adam's "supernumerary bone" [3]. From another religious view of Judaism, when God ponders the creation of Eve, He thinks that

I must not create her from Adam's head, for she would be a proud person, and hold her head high. If I create her from the eye, then she will wish to pry into all things; if from the ear, she will wish to hear all things; if from the mouth, she will talk much; if from the heart, she will envy people; if from the hand, she will desire to take all things; if from the feet, she will be a gadabout. Therefore, I will create her from the member which is hid, that is the rib, which is not even seen when man is naked. [4]

Since the very first moment of her creation, Eve is created in accordance with the image of submission and obedience. She is not allowed to be smarter or more brilliant than her male partner Adam. Accordingly, woman is considered inferior and is defined as the Other to man in the Western gender dichotomy. The sex differences and gender expressions in males and females are settled and hereafter the female struggles for rediscovering her true self behind the stereotypes of gender.

Compared with Book of Genesis, in The Left Hand of Darkness Le Guin provides another version of Genesis, the Hainish universe. In the fictional Hainish universe, human beings evolve on Hain; the planet Gethen, like Terra, an existence as Earth, is part of the colonized planetary system of Hainish people. In Genesis, from God's word is the world created which is full of vitality, whereas Le Guin's world "In the beginning there was nothing but ice and the sun" [5]. The planet Winter, called Gethen in the native language, is always cold. It is three ice-shapes who use their excrement, breath, and soil and sea-water to create the world and human beings. In the creation myth of Orgota, the original human beings are neither men nor women. They are androgynous. Although the first human beings are men and brothers, the elder one Edondurath, in his kemmering, bears children out of his womb with his youngest brother. Instead of the inborn sex, "kemmer" becomes the determinant to an individual's sex. Genly Ai, a native male of Terra, who is sent to the planet of Gethen as an envoy to have the Gethenian join coalition. From his point of view as a sexually permanent male to see the androgynous society, the rigid social conventions of biological sexes and stereotyped gender roles reveal the issue of gender expressions; that is, what is propriety for individuals to perform femininity and masculinity.

\subsection{Heterosexual Concept}

As one of Le Guin's Hainish novels, The Left Hand of Darkness also concerns with her permanent themes of humanity and human relationships. In the relationship between Genly Ai and Estraven, Le Guin questions the controversial dichotomy of sex and gender, especially the question of "what is a woman". Genly Ai represents the male protagonist, while the female one is suspended throughout the fiction. When Estraven asks $\mathrm{Ai}$ "how does the other sex of your race differ from yours?" [5] Ai answers that

the most important thing the heaviest single factor in one's life is whether ones born male or female. In most societies it determines one's expectations, activities, outlook, ethics, manners-almost everything. Vocabulary. Semiotic usages. [. . . ] It's extremely hard to separate the innate differences from the learned ones. Even where women participate equally with men in the society, they still after all do all the childbearing ...." [5]

In heterosexual society, whether an individual behaves properly depends on what sex organ the one has. Femininity is the attributes and behavior generally associated with women. Ai cannot clarify the definition of woman to Estraven whether it relies on physical or psychological aspects. At that moment, "women are more alien to Ai than [Estraven is]" [5]. Ai's perplexity to his female fellows implies that he cannot ascertain to what extent the definition of and relationship between woman and femininity is under biological or social influence.

\subsection{Gender Stereotypes}

In chapter 7 "The Question of Sex," a female investigator reports her observation on Gethenian sexual physiology. Her report explains how the sexual cycle circulates. After the lactation, the female Gethenian will return to the phase of somer and "becomes once more a perfect androgyne. No physiological habit is established" [5]. Le Guin deliberately employs a female investigator to describe the sexual physiology. The female observation about the Gethenians serves as a contrast to Ai's. During kemmer, the Gethenians become sexually male or female, and the sex they adopt can depend on context and relationships. Children-bearing and breast-feeding are a phase in female life circle and after completing the mission, the female Gethenian returns to what he used to be. The status as a mother would not cause any social stereotypes or limits to his identity. The Gethenian way of reproduction of next generation is the most different biological characteristic from Ekumen.

On heterosexual Ekumen only female is able to bear children, and once a woman bears a child in this society, the physiological habit would follow her whole life. However, a Gethenian can be both a father and a mother to his children 
without any influence left from kemmer phase. Through the two reports, Le Guin suggests the idea that "Women's mothering is not an unchanging transcultural universal" [1]. In De Beauvior's "The Mother," she argues the false preconception that "maternity is enough in all cases to crown a woman's life" [3]. The social conventions make women believe that bearing children complete women's self-realization and children serve as an enterprise that she can devote herself wholeheartedly.

The other false preconception is that "the child is sure of being happy in its mother's arms" [3] because maternal love is the most natural to children. In the patriarchal society, women's value lies in their feminine traits. Women is considered having caring nature and good at householdrelated work. It reinforces the idea that child-rearing is women's responsibility. This reveals the problem that the "biological explanations for sex differences have subsumed sociological explanations" [6]. In the ambisexual Gethenian society we find no clues of the social constructs relying on binary gender system. The Gethenians have no physiological habits even though they might play the roles of father and mother at the same time. The changeable biological sex does not give gender the chance to shape a stereotyped image of male or female. Ai observes Estraven and his people from their external behavior, and he hastily categories them into men. He feels confused and annoyed by the effeminate characteristics of Gethenians. He is unable to tell the sex of the Gethenians and further concludes that "They behaved like animals, in that respect; or like women. They did not behave like men" [5]. In fact, he fails to understand their androgynous culture and accordingly ignores the nature of Gethenians. Ai's misunderstanding causes his alienation to the Gethenians and suggests that his observation is based on Earth-like criteria of the category of gender and sex.

The feminist movement in the 1970s met the challenge and the debate about biological determinism in which the biological innate talents of female like child-rearing are discussed. The social expectations from the difference of sex result in the social constructed gender roles to man and woman. Some feminists debate that "there is no scientific evidence for biological determinism of sex differences in behaviour, be it genetic and/or hormonal" [6]. The chromosome "XX" and "XY" decide our biological sexes; however, it is not the determinant to our sexual expressions and behavior. To Le Guin, neither man nor woman should not be limited by the framework of biological sexual differences. Furthermore, she questions the stereotyped gender roles which impose standards on man and woman and thus they are cultivated to meet the masculine and feminine characteristics. Ai's gradual understanding of Estraven exhibits that the gender identity and genderspecific behavior are under social and biological influences which is mutually interacting during one's development.

\section{ANDROGYNY AND HUMANITY}

\subsection{Nature vs. Nurture}

The dichotomy of sex and gender involves the long-lasting debate over "nature" and "nurture". The Gethenian ambisexual society and culture pose the question whether human behavior is determined by the environment, or by individuals' genes. Diane Elam argues that "Where do gender stereotypes come from? Culture. What is culture? A set of stereotypes" [7]. Where does the culture originate? Human society. How does the gender dichotomy become standards to the proper behavior of male and female? Social constructs. Must the balance of the society be based on the gender labor division? Le Guin ponders over the boundaries of the biological sex and the social constructed gender roles and provides a perspective on femininity and masculinity.

Ai's understanding to his opposite sex is similar to his understanding to Estraven whose androgynous culture is out of his reach. Growing up and cultivated on Terra, Ai naturally understands the universe from the perspective of the heterosexual culture. "Nature" is generally viewed as something influenced by genetic inheritance and other biological factors. "Nurture" is what contrasts with inborn characteristics as the influence of external factors. However, when a person exposes in certain environment, experience and learning, these external factors have the possibilities become the determinant of an individual's personality. In other words, nurture has an essential influence on nature.

Although he has already stayed in Karhide more than two years, Ai still has difficulty understanding shifgrethor, a complex set of unspoken social rules and formal courtesy. Ai's masculine mannerisms turn into a barrier to him to communicate with the natives and to understand its culture. For Ai the "Cultural shock was nothing much compare to the biological shock [he] suffered as a human male among human beings who were [. . .] hermaphroditic neuters" [5]. His heterosexual perspective has him regard Estraven, the prime minister of Karhide, as an effeminate man who gives him a "sense of falseness" whenever he thinks of him as a man. Failing to truly cognize and accept the social and cultural differences between Ekumen's heterosexual society and Gethen's ambisexual society, Ai misunderstands Estraven and frustrates his mission of the coalition of humanoid worlds. Unable to properly understand the system shifgrethor, Karhide's most important social norms to behavior, Ai only see and judge the people in Karhide by the appearance.

The difference of sex on Ekumen is one of the determinants to dictate an individual's behavior. One's gender would compel him/her to meet the social or cultural expectations. However, on the ambisexual Gethen, Shifgrethor, which is different from the Terra's social and cultural expectations toward gender roles, serves as a way to identify one's status as well as to dictate the way the Gethenians behave toward one another. The culture formed by Shifgrethor is "not rank, but its opposite, the ability to maintain equality in any relationship, and to do so by respecting the person of the 
other" [8]. Not until Ai has to stay along with Estraven in the Gobrin Ice can he really comprehend the system and then can perceive the influence of his heterosexual consciousness on his relationship with Estraven.

Ai's and Estraven's respective attitudes and perspectives to the humanoid world illustrate that the development of a society and a culture is evolving from certain proportions of "nature" and "nurture". However, to what extent human behavioral traits under the biological or social influence is subject to debate. Le Guin's ambisexual Gethenian society contrasts with the gender stereotypes in a heterosexual society and examines so-called "appropriate" sexual expressions and the construction of gender.

\subsection{Coexistence of Dichotomy}

In the fiction Estraven can be viewed as a "culture hero" who expresses Le Guin's cultural concept [9]. Estraven is educated by Handdara which is a religion modeled on Taoism. One of its principles is the coexistence of opposites. Everything in the world cannot have the one without the other. Compared with Ai's hesitation to accept Gethenians and their culture, Estraven's tolerance of those who differs from him practices Le Guin's ideal of an improved mode of human relationships. For Estraven, love is "not from the affinities and likenesses, but from the difference" [5]. In spite of great cultural differences and difficulties of communication, Estraven trusts and accepts Ai from the beginning without regarding Ai as an alien or a "pervert," a sexually permanent Terra male. Even when $\mathrm{Ai}$ misunderstands and distrusts him, Estraven still saves Ai from his imprisonment and helps him complete his mission of coalition.

The strong dichotomies did harm human relationships. Estraven's tolerance of racial, cultural and physical sexual differences directs the way to achieve a harmonious human relationship. In their eighty-day trek across the frozen land to return Karhide, Ai and Estraven gradually grow an intimacy. Ai's explanation for yin and yang demonstrates the influence of Taoism on Le Guin, who incarnates the sense of unity in Taoism by ambisexual Estraven. The sex/gender dichotomy dissolves in Estraven for who represents "two are one." The manwoman idea is a metaphor to achieve the idea. His feminine characteristics suggests that both man and woman can share the traits of their opposite sex and understand each other. There is no need to view their opposite sex as the Other because the feminine and masculine traits can coexist in a person.

Despite of the fact that it is hard not to be influenced by the socially constructed stereotypes of sex and gender, and the ambisexual society only exists as a utopia in the fiction, it enlightens us a way to see the possibility of the coexistence of opposites and to break down the barrier of communication and then move forward to a society in which the biological sexual differences are no more the obstacle to the understanding between both sexes.

\section{CONCLUSION}

In her introduction of The Left Hand of Darkness, Le Guin expresses the influence she wishes to bring to her readers:

In reading a novel, any novel, we have to know perfectly well that the whole thing is nonsense, and then, while reading, believe every word of it. Finally, when we're done with it, we may find - if it's a good novel-that we're a bit different from what we were before we read it. [5]

Gethen demonstrates Le Guin's idea of harmony, balance and wholeness to humanity. Different from Book of Genesis, Le Guin's Genesis on this metaphysical planet enables readers to rethink the formation of culture and society based on the sexual differences and stereotyped gender roles. We cannot deny our biological sex, but we do not have to ignore our female or male traits existing in us. Le Guin's androgynous society offers a perspective on seeing how a society might evolve if it is without the influence of gender divisions. After understanding Estraven, Ai ultimately opens his eyes to see the alien Estraven who he has misunderstood for a long time. He changes his character and masculine behavior and further develops his androgynous side becoming a more caring and patient person.

Ai's change of his character and Estraven's androgyny suggest that gender expressions do not necessarily connect to biological sex. From the lines of a lay traditional to the fictional planet of Gethen, Le Guin indicates that "Two are one" and "like hands joined together" [5], the coexistence of dichotomy completes an individual's integrity, just like the fundamental relationships of yin-yang in which promotion and restriction coexist to make each other better and reach a balanced and harmonious relationship.

\section{REFERENCES}

[1] Chodorow, N. (1978) Mothering. U of California P, London.

[2] Rose, M. (1981) Alien Encounters: Anatomy of Science Fiction. President and Fellows of Harvard College, New York.

[3] De Beauvoir, S. (2000) One is not born a woman. In: Oliver, K. (Ed), French Feminism Reader, Rowman \& Littlefield, Lanham. pp. 1-34.

[4] Polano, H. (1890) The talmud: selections from the contents of that ancient book, it's commentaries, teachings, poetry and legendsalso brief sketch. DOI: https://books.google.com.tw/books? id=5EApAAAAYA AJ\&pg $=$ PA280\&redir_esc $=\mathrm{y} \# \mathrm{v}=$ onepage $\& \mathrm{q} \& \mathrm{f}=$ false

[5] Le Guin, U. K. (1969) The Left Hand of Darkness. Ace Book, New York. 
[6] Kaplan, G. T., Rogers, L. J. (1990) The definition of male and female: biological reductionism and the sanctions of normality. In: Gunew, S. (Ed), Feminist Knowledge: Critique and Construct, Routledge, London.

[7] Elam, D. (1994) Feminism and Deconstruction. Routledge, New York.

[8] White, D. R. (1999) Dancing with Dragons: Ursula K. Le Guin and the Critics. Camden house, Columbia.

[9] Suvin, D. (1988) Positions and Presuppositions in Science Fiction, Macmillan, London. 